\title{
Wideband Absorbance Measurements: Norms and Middle Ear Disorders
}

\author{
Gwanghui Ryu and Yang-Sun Cho \\ Department of Otorhinolaryngology-Head and Neck Surgery, Samsung Medical Center, Sungkyunkwan University School of Medicine, \\ Seoul, Korea
}

\section{광대역 고막 흡수도 검사의 정상치 및 중이 질환에서의 측정값 비교}

\author{
류 광 희·조 양 선 \\ 성균관대학교 의과대학 삼성서울병원 이비인후-두경부외과학교실
}

Received September 12, 2016

Revised October 31,2016

Accepted November 14, 2016

Address for correspondence

Yang-Sun Cho, MD, PhD

Department of Otorhinolaryngology-

Head and Neck Surgery,

Samsung Medical Center,

Sungkyunkwan University

School of Medicine,

81 Irwon-ro, Gangnam-gu,

Seoul 06351, Korea

Tel +82-2-3410-3578

Fax +82-2-3410-3879

E-mail yscho@skku.edu
Background and Objectives To evaluate the usefulness of wideband tympanometry in predicting middle ear disorders by comparing the absorbance measurements of the disorder and the norm.

Subjects and Method Wideband tympanometry, pure tone audiometry, and endoscopic examination were performed on 284 ears of 190 subjects. Wideband absorbance (WBA) was measured from normal ears (adults: 128 ears, children: 32 ears), disorders of middle ear included effusion (adults: 24 ears, children: 21 ears), tympanic membrane (TM) retraction (adults: 26 ears, children: 6 ears) and perforation (47 adult ears).

Results The normative data of WBA were similar to previous reports from other countries. WBA of the 17-29 age group showed higher values than other age groups at $1600-3150 \mathrm{~Hz}$. Men had higher absorbance at low frequencies whereas women had higher absorbance at high frequencies. There was a significant gender difference at $4000 \mathrm{~Hz}$. Adults showed higher absorbance at 1000,1250 , and $1600 \mathrm{~Hz}$ and lower absorbance at 2500,3150 , and $4000 \mathrm{~Hz}$ than children did at those respective frequencies. Compared to the normal group, WBA was decreased at all frequencies by more than $500 \mathrm{~Hz}$ in ears with middle ear effusion and at most frequencies by less than $2000 \mathrm{~Hz}$ in ear with TM retraction. TM perforation showed higher absorbance in low frequencies; the absorbance decreased as the size of perforation increased. Conclusion The present study established normative WBA data and the results showed comparable statistics to former studies in age and gender difference. WBA provided a high reliability in discrimination of middle ear effusion and TM retraction. WBA is a simple, non-invasive and useful diagnostic tool for middle ear disease.

Korean J Otorhinolaryngol-Head Neck Surg 2017;60(2):55-62

Key Words Otitis media with effusion - Tympanic membrane perforation ·

Wideband absorbance.

\section{서 론}

중이염을 포함한 중이 질환은 매우 흔하며 질병의 종류 또 한 다양하다. 특히 소아에서 삼출성 중이염의 경우 연령이 증 가할수록 유병률이 감소하지만 높게는 $16.4 \%$ 까지 보고되며 국민건강영양조사에 따르면 소아에서 병원을 방문하는 질환
중 7번째로 흔한 질환으로 알려져 있다. ${ }^{1-3)}$ 이외에도 흔한 중 이 질환에는 고막 함몰, 고막 천공 등이 있을 수 있으며 이와 같은 질환을 진단할 수 있는 방법은 이내시경을 통해 직접 고 막 소견을 확인하여 진단하는 방법과 통기 이경을 이용하여 고막의 가동성을 확인하는 방법이 있다. 또한 고막 소견만으로 정확한 진단을 내리기 어려운 경우 임피던스 청력검사(imped- 
ance audiometry)를 시행하여 고실도의 형태를 확인하여 진단 할 수 있는데, 삼출성 중이염의 경우 진단의 민감도는 $94.4 \%$ 로 보고되고 있다. ${ }^{4)}$ 임피던스 청력검사에는 고막 운동성 계측 또는 고실도 검사(tympanomtery), 등골반사(acoustic stapedial reflex), 외이도의 용적 및 정적 탄성 계측, 그리고 등골반 사피로(acoustic reflex decay) 등이 포함된다.5)

고실도 검사에서 측정하는 고막의 흡수도(absorbance)와 반 사도(reflectance)는 고막의 상태뿐만 아니라 중이 내의 질량 효과(mass effect) 및 강직도(stiffness)를 반영할 수 있는 검사 법이다. ${ }^{6)}$ 귀에 소리 압력을 가한 후 중이에서 흡수되는 음향 에너지 양이 흡수도이고 반사된 에너지의 양이 반사도이므로 고막에서 소리 에너지의 반사도와 흡수도는 총 합이 1이 되는 관계(흡수도=1-반사도)이다. 기존의 고실도 검사는 고정된 주 파수 $(226 \mathrm{~Hz})$ 에서 외이도의 압력 변화에 따른 에너지 흡수 도의 변화를 나타낸 것이다. 단일 주파수 대신에 광대역 주파 수 자극(226 2000 Hz, 20개 주파수)을 이용한 중이의 에너 지 흡수율과 반사율을 측정하는 연구는 1993년에 보고되었 는데, ${ }^{78)}$ 삼출성 중이염의 경우 단일 주파수 고실도 검사보다 광대역 주파수 고실도 검사(multifrequency tympanometry) 의 민감도가 높았으며 이경화증 환자에서도 정상과 이경화증 을 감별하는 데 있어 광대역 주파수 고실도 검사가 우월하다고 보고되었다.,10) 이후 더 넓은 주파수 영역(0.25 11.3 kHz)에 서 압력의 변화에 따른 반사도를 측정하는 광대역 고막 반사 도(wideband reflectance)가 소개되었는데, 이는 압력, 주파수, 반사도를 각 축으로 하는 3차원의 그래프로 표시할 수 있었 으며, 정상 성인, 소아 및 신생아에서 광대역 고막 반사도를 이 용한 많은 연구가 발표되었다. ${ }^{11-14)}$ Shahnaz와 Bork ${ }^{15)}$ 는 정상 성인과 소아에서의 표준 정상치(norm)와 함께 백인과 중국 인에서 인종적 차이에 대해 분석을 하였는데, 그 결과 성인에 서 고주파의 반사도는 중국인의 수치가 낮고 저주파의 반사 도는 백인에서 낮은 것으로 나타났으며 소아에서도 비슷한 결과를 얻었다. ${ }^{16}$ 초기 연구에는 Keefe 등 ${ }^{17)}$ 이 1992년에 개발 하여 발표한 임피던스 측정 기계를 이용하여 주로 압력을 가 하지 않은 상태(ambient pressure)에서 주파수 변화에 따른 고막의 반사도를 측정할 수 있었으며, 정상치와 삼출성 중이 염, 이경화증, 이소골 단절, 고막 천공 등의 중이 질환에서 광 대역 고막 반사도의 측정값을 비교하였다. ${ }^{18,19)}$ 2006년부터는 상품화되어 개발된 장비(RMS system; Mimosa Acoustics Inc., Champaign, IL, USA)를 이용한 결과들이 발표되었다. ${ }^{14,15)}$

2003년에 Keefe와 Simmons ${ }^{19)}$ 는 흡수도를 측정하게 되면 주파수와 압력에 따라 중심 최대값이 존재하여, 이는 반사도 와는 다르게 측정값의 적률(moment)을 분석하여 전체적인 분 포 모양을 비교할 수 있으며, 또한 기존의 고실도 검사와 같은
측정치를 사용하므로 결과를 해석하기에 더 친숙하고 유용 하다고 하였다. 이후 상용화된 장비(AT235; Interacoustics, Assens, Denmark)를 이용하여 흡수도를 측정한 연구들이 발 표되었다. 광대역 고막 흡수도(wideband absorbance) 검사는 수 초 이내에 광범위의 주파수에서 압력 변화에 따른 흡수도 를 측정할 수 있으며 측정된 수치를 바탕으로 특정 압력 및 특정 주파수에서의 흡수도를 구할 수 있다. ${ }^{20,21)}$

고실도를 포함한 기존의 임피던스 청력검사는 외이도 자체 의 탄력성, 체적 등에 의해 오차가 발생할 수 있다. 소아의 경 우 생후 2개월이 지나야 안정된 검사 수치를 얻을 수 있으며, ${ }^{22}$ 7개월 미만의 유아에서는 $226 \mathrm{~Hz}$ 의 고실도 검사를 통해 삼 출성 중이염의 유무를 정확히 구별하기가 어렵다고 알려져 있다. ${ }^{23)}$ 통기 이경(pneumatic otoscope)은 삼출성 중이염에서 고막의 가동성을 관찰할 수 있는 좋은 방법이지만 그 해석 은 검사자에 따라 주관적일 수 있다. ${ }^{24)}$ 기존의 검사들에 비해 광대역 고막 흡수도는 짧은 시간 내에 측정이 가능하며 외이 도의 상태에 영향을 적게 받고 측정법이 간단하다는 장점이 있다.

본 연구에서는 광대역 고막 흡수도의 정상치를 측정하고 기 존 보고와 비교하고자 하였다. 또한 중이 질환에서의 측정값 을 정상치와 비교하여 다양한 중이 질환에서의 광대역 고막 흡수도의 진단적 가치에 대하여 알아보고자 하였다.

\section{대상 및 방법}

\section{대상 환자의 선택}

2014년 5월부터 12월까지 내원한 외래 환자를 대상으로 정 상군과 중이 질환군을 모집하였다. 정상군에는 정상 고막 소 견을 보이고 순음청력검사에서 $25 \mathrm{~dB}$ 이하의 정상 청력이 확 인된 대상자가 포함되었고, 귀 내시경 검사 및 순음청력검사 로 삼출성 중이염, 고막 함입, 고막 천공으로 진단된 환자를 중이 질환군에 포함시켰다. 삼출성 중이염은 고막 전체에 삼 출액이 차 있는 경우 검사를 시행하였으며, 고막 함입은 상고 실 함입, 고막 이완부 함입을 모두 포함하였으며 상고실에 진 주종이 있는 경우는 제외하였다. 또한 정상 고막 소견을 보이 면서 전음성 난청으로 확인된 경우도 제외하였다. 고막 천공의 경우 천공의 크기에 따라 분류(작음, 중간, 큼)하였으며, 고막 전체가 천공된 환자는 측정이 어려워 제외하였다.

총 190명의 환자에서 284귀를 검사하였다. 광대역 고막 흡 수도 검사에 사용된 기계에 설정되어 있는 소아 연령 기준과 동일하게 3 16세까지를 소아군으로 정하였는데, 이는 이전에 발표된 연구에 따라 정해진 기준이다. 소아 44 명의 총 59 귀에 서 검사를 시행하였으며, 정상 32 귀, 삼출성 중이염 21 귀, 고막 
Table 1. Demographics of subjects

\begin{tabular}{lcccccc}
\hline \multicolumn{1}{c}{ Group } & Age mean (range) & Gender, M:F (\%) & Right & Left & Ear & Subjects \\
\hline Normal (adults) & $49.2(18.6-77.8)$ & $50: 78(39.1: 60.9)$ & 66 & 62 & 128 & 98 \\
& $17-29$ years & & 8 & 10 & 18 & 14 \\
& $30-39$ years & & 10 & 7 & 17 & 12 \\
& $40-49$ years & & 12 & 13 & 25 & 19 \\
& $50-59$ years & & 26 & 16 & 42 & 33 \\
& Over 60 & & 10 & 16 & 26 & 20 \\
Normal (children) & $9.6(4.0-15.6)$ & $20: 12(62.5: 37.5)$ & 15 & 17 & 32 & 29 \\
Effusion (adults) & $48.6(20.0-82.0)$ & $16: 8(66.7: 33.3)$ & 12 & 12 & 24 & 15 \\
Effusion (children) & $6.2(2.7-13.9)$ & $12: 9(57.1: 42.9)$ & 11 & 10 & 21 & 15 \\
Retraction (adults) & $51.2(17.4-82.3)$ & $8: 18(30.8: 69.2)$ & 15 & 11 & 26 & 22 \\
Retraction (children) & $9.0(5.7-13.1)$ & $5: 1(83.3: 16.7)$ & 4 & 2 & 6 & 6 \\
Perforation (adults) & $57.2(37.4-78.0)$ & $22: 21(51.2: 48.8)$ & 18 & 29 & 47 & 43 \\
\hline Total & & & & & 284 & 190 \\
\hline
\end{tabular}

함입 6귀가 포함되었다. 17세 이상 성인 146명에서는 정상 128 귀, 삼출성 중이염 24귀, 고막 함입 26귀, 고막 천공 47 귀를 검사하였다. 정상 성인의 경우에는 나이대별로 5 개의 범주 (17 29세, 30 39세, 40 49세, 50 59세, 60세 이상)로 구분하 여 비교하였다(Table 1). 본 연구는 연구 시작 이전에 기관윤리 심의위원회의 승인(IRB No. SMC 2014-12-022)을 받았다.

\section{광대역 고막 흡수도 측정}

광대역 고막 흡수도 검사는 Titan ${ }^{\circledR}$ (Interacoustics)을 이용 하여 측정하였다. 대상자의 외이도에 나이에 맞게 권고되는 크기의 탐침(ear probe)을 삽입한 후 기기에서 자동으로 226 $\mathrm{Hz}$ 에서 $8000 \mathrm{~Hz}$ 의 광대역 주파수 소리와 함께 $-400 \mathrm{daPa}$ 에서 $+200 \mathrm{daPa}$ 의 압력이 주어졌다. 10초 내외의 시간 동안 자동화된 프로그램을 통해 압력 변화에 따른 각 주파수에서 의 에너지의 흡수율이 측정되었다. 결과는 3 차원 그래프로 표 시되었으며 이 중 주변 대기압(ambient pressure)에서 각 주파 수에서의 흡수율을 이용하여 분석하였다.

\section{통계적 분석}

정상군에서 연령별 차이는 Kruskal-Wallis 검정을 이용하 여 분석하였으며, 사후 검정으로는 순위를 이용한 Tukey 검정 을 사용하였다. 성별과 귀의 측에 대해서는 독립표본 $\mathrm{t}$-검정 또는 Mann-Whitney 검정을 이용하여 분석하였다. 정상군과 질환군의 차이 또한 독립표본 t-검정 또는 Mann-Whitney 검 정을 이용하였으며, Shapiro-Wilk 검정을 통해 변수의 정규 성 검정을 시행하여 정규성을 만족하는 주파수에 대해서만 독 립표본 $\mathrm{t}$-검정을 시행하였다. 통계적 유의성은 사후 검정(Bonferroni adjustment)을 통하여 $p=0.003$ 이하를 유의한 것으 로 간주하였다. 두 군의 평균을 분석한 결과에 대해 효과크
기(Cohen's d)를 추가로 계산하여 두 군의 차이를 확인하였으 며 0.8 이상을 효과크기가 큰 것으로 간주하였다. ${ }^{25)}$ 통계 분석 에는 SPSS 20(SPSS Inc., Chicago, IL, USA)을 사용하였다.

\section{결 과}

\section{정상치 측정 및 연령대별 비교}

정상 성인환자의 나이대별 분포는 17 29세 18귀, 30 39세 17귀, 40 49세 25귀, 50 59세 42귀, 60세 이상 26귀였다. 성별 은 남자 50귀, 여자 78 귀이며 우측 66귀, 좌측 62 귀였다. 전체 정상 성인의 흡수도 및 나이 분포에 따른 흡수도 수치는 Fig. 1 에 제시하였다. 회색으로 표시된 영역은 $\mathrm{Liu}$ 등 $^{20}$ 이 $33.8 \pm$ 10.0 세의 성인 48명에서 측정하여 발표한 정상 수치의 10 90 백분위수이며, 밝은 회색의 영역은 5 95 백분위수 영역이다. 정상 성인 전체 평균 수치는 10 90 백분위수 안에 속하는 것 을 알 수 있으며, 연령대별 수치 또한 대부분이 10 90 또는 5 95 백분위수 영역 안에 존재하였다. 또한 같은 연령대인 30 39세의 고막 흡수도 수치가 Liu 등이의 연구에서 제시된 백분위수 그래프의 모양과 가장 비슷한 것으로 보아 본 연구 에서 측정한 정상치는 서양인에서의 정상 수치와 유사한 것 을 알 수 있었다.

정상 성인의 연령대를 5 개의 범주(17 29, 30 39, 40 49, $50 ~ 59,60$ 세 이상)로 나누었을 때 각 주파수별로 흡수도의 연 령대에 따른 차이는 $1250 \mathrm{~Hz}$ 를 제외한 모든 주파수에서 통계 적으로 유의하였다 $(p<0.05)$. 중간 주파수 $(1600 ~ 3150 \mathrm{~Hz})$ 에 서는 17 29세가 다른 연령대보다 높은 흡수도를 보였고, 특히 $2500 \mathrm{~Hz}$ 에서 17 29세 연령대는 다른 연령대 모두와 유의한 차이가 있었다.

정상 성인의 성별에 따른 흡수도의 차이를 비교하였을 때, 
저주파의 흡수도는 남성에서 높게 나타났고 고주파의 흡수도 는 여성에서 더 높았지만 통계적으로는 $4000 \mathrm{~Hz}$ 에서만 차이 가 있었다 $(p=0.002)$ (Fig. 2A). 동일한 방법으로 분석하였을 때, 우측 귀와 좌측 귀는 차이가 없었다(Table 2).

성인과 소아를 비교한 결과 $800,1000,1250 \mathrm{~Hz}$ 및 2500, $3150,4000 \mathrm{~Hz}$ 에서 통계적으로 유의한 차이 $(p<0.003)$ 가 있었 다. $1600 \mathrm{~Hz}$ 까지는 성인의 흡수도 값이 더 높았으며 $2000 \mathrm{~Hz}$ 이후부터는 소아의 흡수도 값이 더 높게 나타났다(Fig. 2B). 이 중에서 두 군 간의 차이가 가장 큰 주파수는 $3150 \mathrm{~Hz}$ (Cohen's $\mathrm{d}=1.07)$ 였다.

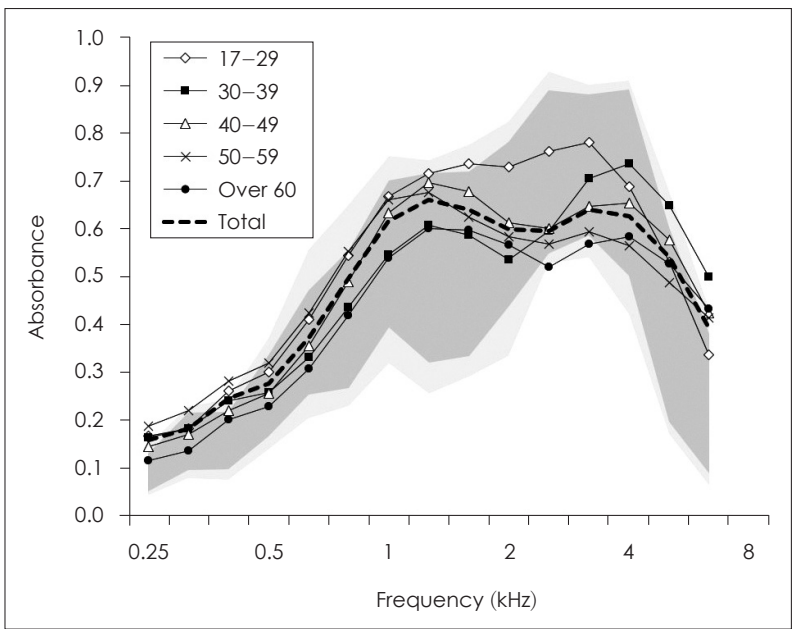

Fig. 1. Wideband absorbance displayed in relation to frequencies. Dotted line indicates a mean wideband absorbance in adults, and solid lines with symbols indicate the mean absorbance according to the age group. The shaded area with gray color represents the $10-90$ th percentiles of norms from Liu et al. ${ }^{20)}$ and light gray color represents 5-95th percentiles. Adapted from Liu, et al. J Acoust Soc Am 2008;124(6):3708-19, with permission of J Acoust Soc $\mathrm{Am}^{20)}$

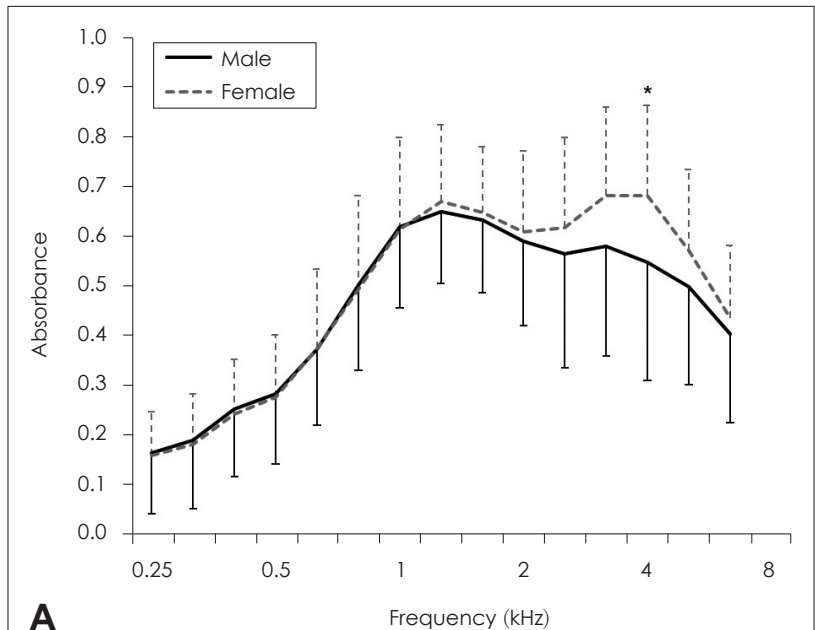

\section{중이 질환의 측정값 비교}

성인에서의 삼출성 중이염과 고막 함입을 정상 흡수도와 비교하였을 때 고막 함입, 삼출성 중이염 순으로 고막 흡수 도가 감소하였다(Fig. 3A). 고막 함입의 경우 $250,400,500$, $620,800,1000,1250,1600,2000 \mathrm{~Hz}$ 에서 정상군에 비해 통 계적으로 유의한 차이를 보였으며, 삼출성 중이염에서는 500 $\mathrm{Hz}$ 이상 모든 주파수에서 유의한 차이를 보였다 $(p<0.003)$. 정상군과 가장 큰 차이가 나는 주파수는 고막 함입에서는 $1250 \mathrm{~Hz}$ (Cohen's d=1.77), 삼출성 중이염에서는 $1600 \mathrm{~Hz}$ (Cohen's d=2.38)였다. 고막 함입과 삼출성 중이염의 흡수도 를 비교하였을 때에는 $2500,3150,4000 \mathrm{~Hz}$ 3개의 주파수에

Table 2. Comparison of the wideband absorbance values according to the age group $(17-29,30-39,40-49,50-59$, over 60$)$, gender, side (right or left), and frequency

\begin{tabular}{cccc}
\hline Band $(\mathrm{Hz})$ & Age group ${ }^{\dagger}$ & Gender & Side \\
\hline 250 & $0.028^{*}$ & $0.764^{\ddagger}$ & $0.208^{\ddagger}$ \\
315 & $0.022^{*}$ & $0.832^{\ddagger}$ & $0.206^{\ddagger}$ \\
400 & $0.049^{*}$ & $0.940^{\ddagger}$ & $0.224^{\ddagger}$ \\
500 & $0.041^{*}$ & $0.951^{\ddagger}$ & $0.306^{\ddagger}$ \\
620 & $0.017^{*}$ & $0.949 \ddagger$ & $0.274^{\ddagger}$ \\
800 & $0.011^{*}$ & $0.825^{\S}$ & $0.118^{\S}$ \\
1000 & $0.023^{*}$ & $0.861 \S$ & $0.061 \S$ \\
1250 & 0.101 & $0.479 \S$ & $0.126^{\S}$ \\
1600 & $0.006^{*}$ & $0.568^{\S}$ & $0.441^{\S}$ \\
2000 & $0.004^{*}$ & $0.514^{\ddagger}$ & $0.537 \S$ \\
2500 & $0.002^{*}$ & $0.285^{\ddagger}$ & $0.808^{\ddagger}$ \\
3150 & $0.005^{*}$ & $0.010^{\ddagger}$ & $0.673^{\ddagger}$ \\
4000 & $0.029^{*}$ & $0.002^{* \ddagger}$ & $0.851^{\ddagger}$ \\
5000 & $0.019^{*}$ & $0.027 \S$ & $0.188^{\S}$ \\
6300 & $0.021^{*}$ & $0.277 \S$ & $0.059 \S$ \\
\hline
\end{tabular}

$* p<0.05$ was considered statistically significant, ${ }^{\prime}$ Kruskal-Wallis test, ¥Mann-Whitney test, \$two sample t-test

Fig. 2. Comparison of mean wideband absorbance and standard deviation (vertical error bars) between male and female (A), and between adults and children (B). The asterisk (*) indicates statistical significance. 
서 차이가 있었다 $(p<0.001)$. 정상, 고막 함입, 삼출성 중이염의 실제 검사 결과를 나타내는 3D 그래프는 Fig. $3 \mathrm{C}, \mathrm{D}$, and $\mathrm{E}$ 와 같다. 삼출성 중이염 24귀 중 고막 함입이 동반된 경우는 16 귀(66.7\%)였으며 동반되지 않은 경우와 비교하였을 때 전 주 파수에서 흡수도의 차이는 없었다.

\section{소아에서도 성인과 마찬가지로 정상, 고막 함입, 삼출성 중}

이염 순으로 갈수록 흡수도가 감소하는 것을 확인할 수 있 었고, 성인과 차이가 가장 큰 차이를 보이는 $3150 \mathrm{~Hz}$ 에서 최 고값을 나타내며 그래프의 전체적인 모양은 유지되는 것을 알 수 있다(Fig. $3 \mathrm{~B}$ ). 소아의 정상군과 삼출성 중이염의 흡수도 를 비교하였을 때, $400 \mathrm{~Hz}$ 에서 $6300 \mathrm{~Hz}$ 까지 모든 주파수에 서 차이를 보였으나 $(p<0.001)$, 고막 함입은 정상군 및 삼출성

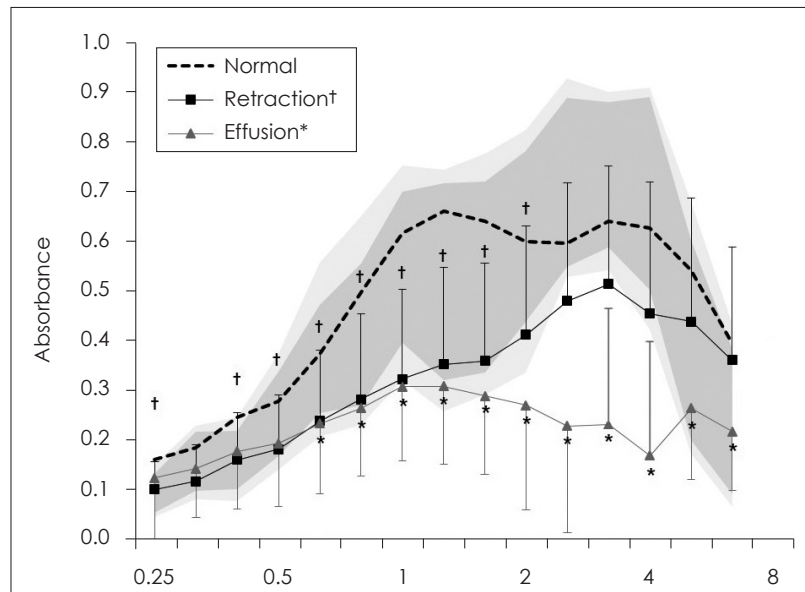

A

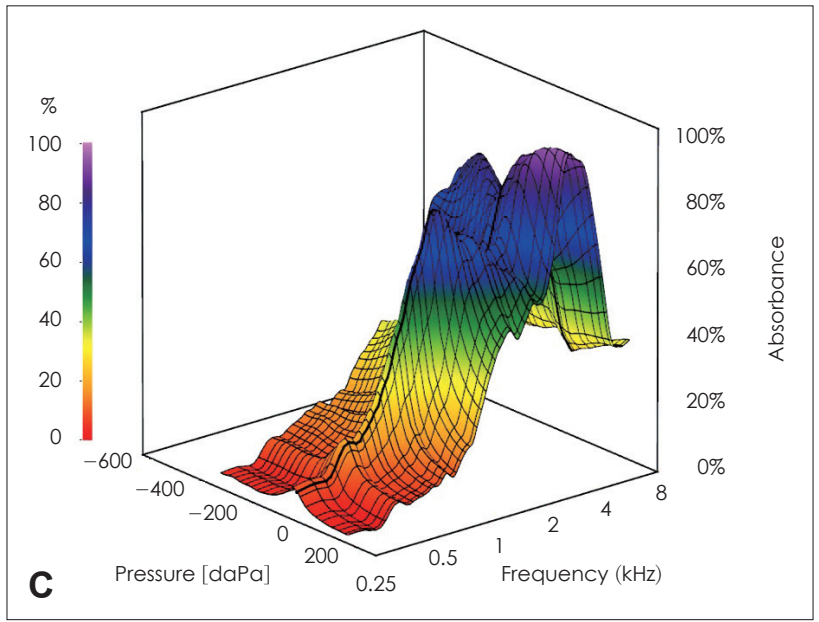

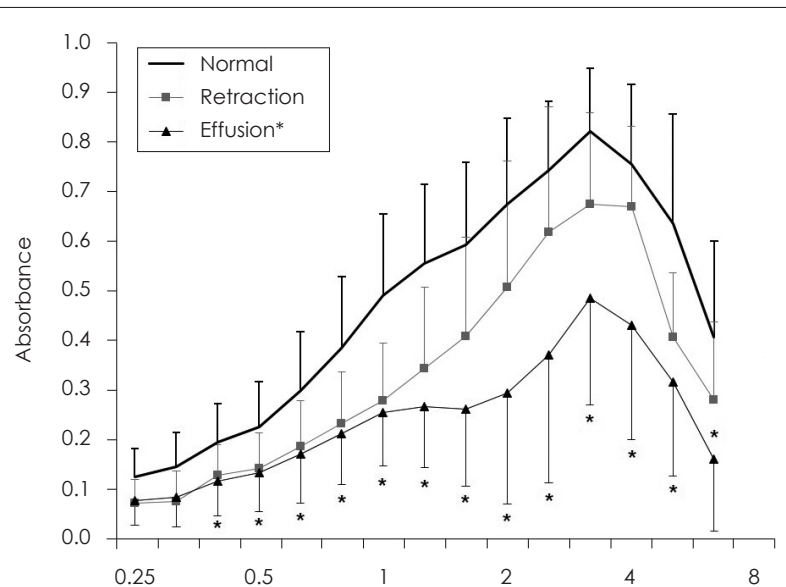

B Frequency $(\mathrm{kHz})$

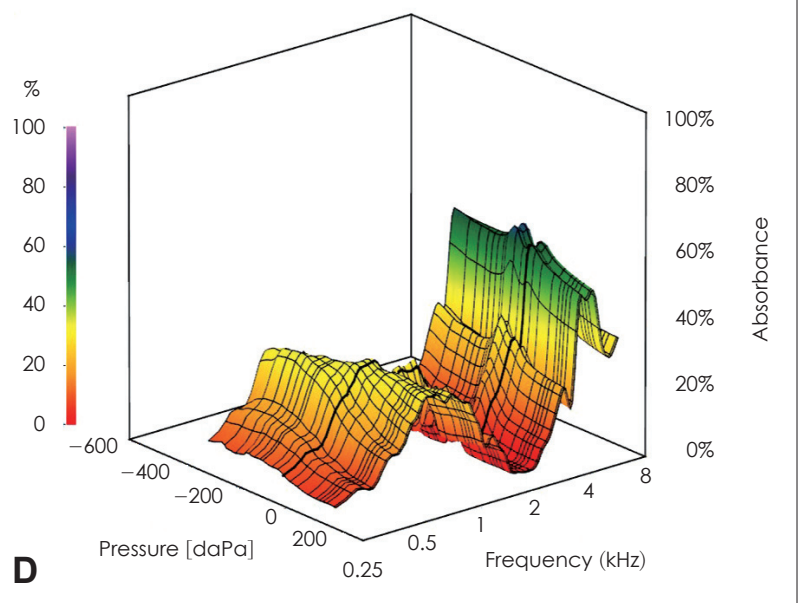

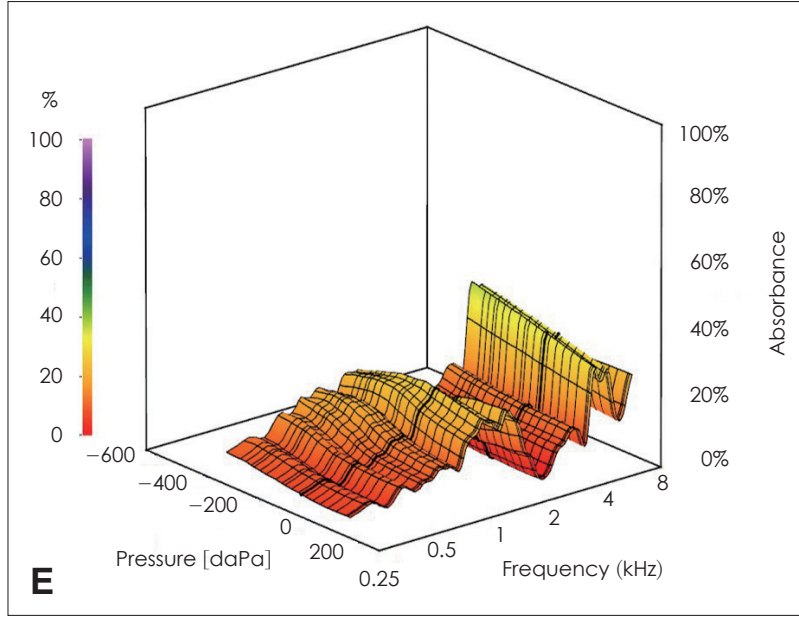

Fig. 3. Comparison of mean wideband absorbance and standard deviation (vertical error bars) among normal, effusion, and retraction group in adults $(A)$, and comparison among normal, effusion and retraction in children $(\mathrm{B})$. The asterisk $(*)$ indicates statistical significance between normal and effusion group and the dagger $\left({ }^{\dagger}\right)$ for normal and retraction group. Representative 3D graphs of wideband absorbance were shown for normal $(C)$, retraction (D), and effusion (E) groups. 


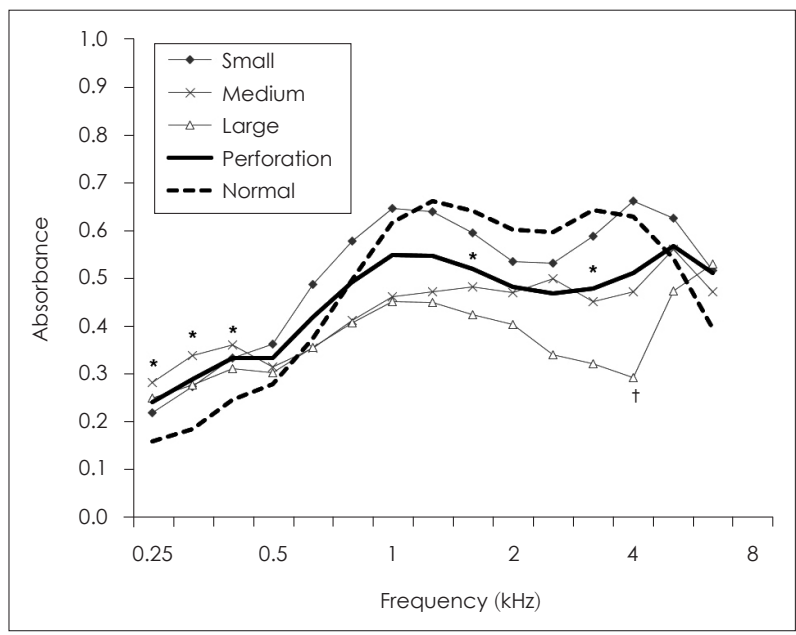

Fig. 4. Comparison of normal, whole group of tympanic membrane perforation and three sizes of perforation. Error bar was not shown for the sake of readability. The asterisk (*) indicates statistical significance between normal and perforation group and the dagger $\left(^{\dagger}\right)$ for small and large perforation group.

중이염과 통계적으로 유의한 차이를 보이지 않았다. 소아에서 고막 함입이 동반된 삼출성 중이염은 21귀 중 8귀(38.1\%)였 으며, 성인과 마찬가지로 고막 함입이 동반되지 않은 경우와 비교하여 유의한 차이는 없었다.

성인에서 고막 천공 환자 전체의 고막 흡수도를 정상과 비 교한 결과, $400 \mathrm{~Hz}$ 이하의 저주파에서 정상보다 높았으며 $(p<$ $0.003), 1600,3150 \mathrm{~Hz}$ 에서는 정상보다 낮았다 $(p<0.003)$. Fig. 4에서는 정상, 전체 고막 천공 환자, 고막 천공의 크기별 흡수도 수치를 나타내었다. 고막 천공의 크기에 따라 분석하 였을 때, 고막 천공의 크기가 커질수록 흡수도가 감소하는 경향은 있으나 통계적으로 유의한 차이는 없었으며, $4000 \mathrm{~Hz}$ 단 하나의 주파수에서 천공의 크기가 작은 그룹과 큰 그룹에 서 차이가 있었다 $(p<0.001)$.

\section{고 찰}

고막의 흡수도 및 반사도에 영향을 미치는 것은 중이의 상 태, 고막의 두께, 외이의 상태 등이 있으나 광대역 고막 반사 도 검사는 기존의 고실도 검사와 다르게 외이의 상태에 의해 크게 영향을 받지 않고 중이의 상태를 민감하게 반영한다는 장점이 있다. 기존 고실도 검사의 경우 검사 시 외이도 밖으로 압력이 새어나가지 않도록 외이도와 탐침 사이가 완전히 봉 인(sealing) 되어야 한다. 하지만 광대역 고막 반사도는 대기압 (ambient pressure)에서 측정 시에는 탐침이 완전히 봉인될 필 요가 없으므로 외이의 상태에 의해 크게 영향을 받지 않고 중 이의 상태를 민감하게 반영할 수 있으며, 검사를 측정하는 시 간이 약 10 초 내외로 임상적으로 유용하다. ${ }^{20,34)}$
지금까지 광대역 고막 반사도 또는 흡수도의 정상치를 보 고하는 많은 연구가 있지만, 대부분 특정 연령대를 대상으로 하고 있고, 주로 소아에 대한 연구가 많으며 정상 성인을 연 령대에 따라 분류하여 정상치를 제시한 연구는 발표된 바가 없다. 일례로 $\mathrm{Liu}$ 등 $^{20}$ 의 연구에서 대표적인 성인의 정상치를 제시하였는데 이 수치는 백인만을 대상으로 하였으며 나이 범 위(33.8 \pm 10 세) 또한 전 연령대를 포함하지 않았다. 본 연구는 한국인을 대상으로 광대역 고막 흡수도 검사를 시행하였으며 연령대 또한 2.7 82.3세까지 광범위한 연령대를 포함하였다.

\section{정상치 측정 및 연령대별 비교}

정상 성인의 검사 결과는 평균 $33.8 \pm 10$ 세의 환자를 대상으 로 한 Liu 등 ${ }^{20}$ 의 연구에서 제시한 성인 정상치의 5 95\% 수 치에 모두 포함되는 것을 확인할 수 있었다. 본 연구에서는 이 연구보다 넓은 연령대를 대상으로 하였으며 연령대별로 비교 분석하였다. 연령대별 고막 흡수도를 나타낸 Fig. 1에서 본 연구의 30 39세의 고막 흡수도 수치가 Liu 등 ${ }^{20}$ 의 연구에서 제시된 5 95\%, 10 90\% 그래프의 모양과 가장 비슷한 것을 알 수 있다. 17 29세 연령대는 고주파에서 성인 전체의 평균보 다 고막 흡수도 값이 높았는데 그 이유로 이 연령대에 성장기 연령이 포함된 영향을 배제할 수는 없다. 그 이상의 연령대는 평균과 비슷하거나 평균보다 낮은 고막 흡수도를 보였으나 연령대에 따라 순차적으로 고막 흡수도가 감소하는 경향성 은 나타나지 않았으며 연령대 그래프의 순서도 주파수 범위에 따라 변하는 것을 알 수 있었다. 따라서 정상 성인 전체는 특 정 범위 안에서 비슷한 값을 나타내지만 연령에 따른 경향성 은 없다는 것을 확인할 수 있었다. 18 28세의 젊은 성인과 60 85세의 노인을 비교한 연구에서는 저주파에서는 노인의 고막 반사도가 더 낮고 고주파에서는 반사도가 더 높게 나타 났는데, ${ }^{13)}$ 나이가 들면서 중이 근육의 장력이 감소하여 중이 의 이소골과 고막의 강직도가 감소하기 때문에 발생한다고 설명하고 있다. ${ }^{26)}$ Doan 등 ${ }^{26}$ 은 쥐에서 나이에 따른 변화를 연 구하였고 나이에 의한 근육의 장력, 중이 내 인대와 이소골 관 절의 변화가 이소골의 회전축을 변화시키고 중이 내 관성이 변하게 되어 고주파에 대한 반응의 차이가 발생한다고 설명 하였다. 본 연구에서 17 29세와 60세 이상의 두 연령대를 비 교해 보았을 때 저주파에서는 차이가 없었으나 1600,2500 , 3150 의 세 주파수에서 유의한 차이가 있었다.

기존 연구에서 성인과 소아의 차이는 $315 \sim 1250 \mathrm{~Hz}$ 사이에 서 소아가 더 높은 반사도 값을 나타내고 $2500 ~ 5000 \mathrm{~Hz}$ 에 서는 성인의 반사도가 더 높았다. ${ }^{16)}$ 이는 소아에서 고주파에 대한 소리 흡수도가 더 높다는 것을 뜻하며 본 연구에서도 $2000 \mathrm{~Hz}$ 이상 주파수에서는 소아의 흡수도가 높게 나타났다. 
중이 구조가 성장할수록 이소골과 등골의 족판(footplate), 고막 자체의 크기가 커져서 성인이 소아에 비하여 질량 효과 가 커지는 것에 의해 나타나는 현상으로 볼 수 있으며 ${ }^{27)}$ 질량 이 커질수록 중이의 고주파 소리 전달 효율이 감소하여 성인 에서는 고주파의 흡수도가 감소한다.

중국인과 백인을 비교한 연구에서 저주파의 반사도는 중 국인이 높고, 고주파의 반사도는 백인이 높게 측정되었다. ${ }^{15,16)}$ 그 이유로는 인종 간 신체 크기의 차이에 따라 중이강의 용량 도 차이가 나는데, ${ }^{28)}$ 중이강이 클수록 강직도가 감소하므로 중이강의 크기가 큰 백인에서 저주파의 반사도는 감소하고 흡수도는 증가하는 것으로 설명할 수 있다. 마찬가지로 성별 차이는 젊은 성인에서 저주파에서는 중이강의 크기가 작은 여 성의 반사도가 더 높고 고주파에서 남성의 반사도가 더 높다 고 알려져 있다. ${ }^{11)}$ 본 연구에서도 저주파의 흡수도는 남성이 높고 고주파의 흡수도는 여성에서 더 높은 것을 확인할 수 있 었고 $4000 \mathrm{~Hz}$ 에서 유의한 차이가 있었다 $(p=0.002)$ (Fig. 2A).

\section{중이 질환의 측정값 비교}

1 세경의 소아에서 정상군과 삼출성 중이염을 비교한 연구 에서 광범위 고막 흡수도는 정상과 삼출성 중이염을 구별하 는 데 $90 \%$ 의 정확도를 보였고, 고막의 강직도가 증가할수록 에너지 흡수도는 감소한다고 보고하였다. ${ }^{29)}$ 이는 본 연구에 서 고막 함입과 삼출성 중이염의 고막 흡수도 수치가 단계적 으로 감소하는 것과 동일한 결과이며, 중이강 내에 삼출물이 생기기 전, 고막 함입이라는 변화가 먼저 발생한 후 삼출성 중이염으로 발전하는 일련의 과정임을 유추할 수 있다. 이러 한 특징은 성인과 소아 모두에서 동일하게 관찰되었다.

고막 천공의 경우 2 명의 고막 천공 환자에서 광범위 고막 반 사도를 측정하였던 연구와 마찬가지로 저주파에서 정상보다 더 높은 에너지 흡수를 보였다. ${ }^{18)}$ 이외의 주파수에서 2 명의 환 자의 고막 반사도는 정상 범위에 존재하였지만 비전형적인 모양을 나타냈으며 본 연구의 결과에서 역시 다른 질환보다 표준 편차가 더 큰 것을 알 수 있었다. 고막 천공의 크기에 따 라 분류하여 광대역 고막 흡수도를 분석한 연구는 발표된 바 가 없었으며, 본 연구에서 천공의 크기가 증가함에 따라 흡수 도가 감소하는 경향을 나타내는 것을 확인할 수 있었다. 고막 천공에 대한 피험자 수가 늘어나면 통계적으로 유의한 결과 를 얻을 수 있을 것으로 기대된다.

현재 광대역 고막 흡수도 또는 반사도에 대하여 가장 관심 을 가지고 활발히 연구되고 있는 분야는 신생아에서 중이 질 환을 감별할 수 있는가에 대한 주제이다. 신생아 청력 선별검 사에 추가적으로 고막 반사도 검사를 시행할 경우 정확도를 높일 수 있다는 많은 연구 결과가 보고되고 있으며, ${ }^{12,21,30)}$ 신생
아에서 광대역 고막 흡수도 검사를 이용하여 전음성 난청을 구별할 수 있다는 결과도 발표되었다. ${ }^{31)}$ 신생아의 경우 출생 직후에는 중이강 내에 양수, 중배엽성 조직, 태변 등이 남아 있을 수 있으며 이것은 삼출성 중이염과 비슷한 물리적 특성 을 나타낼 수 있다. ${ }^{32,33)}$ 이러한 경우에 중이의 소리 전달의 효율 성이 변하게 되어 신생아 청력 선별검사 결과에 영향을 미칠 수 있다. 신생아 청력 선별검사 방법 중 하나인 이음향 방사검사의 통과 또는 재검 결과를 예측할 수 있는 분별력은 $1 \mathrm{kHz}$ 고실 도 검사보다 광대역 고막 반사도 검사가 더 우월하다고 보고 되었다. ${ }^{34)}$ 따라서 신생아에 대해서도 추후 정상치를 검사하여 우리나라에서도 신생아 청력 선별검사의 추가적인 진단도구 로 활용할 수 있도록 하여야 할 것이다.

또한 삼출성 중이염, 고막 함입, 고막 천공 이외에 이소골 단 절 또는 고정, 고실경화증 등 다양한 중이 질환에 대한 광대 역 고막 흡수도 검사의 유용성에 대한 연구도 필요할 것으로 사료된다.

\section{REFERENCES}

1) Kim CS, Jung HW, Yoo KY. Prevalence of otitis media and allied diseases in Korea--results of a nation-wide survey, 1991. J Korean Med Sci 1993;8(1):34-40.

2) Kim JG, Sohn YT. Prevalence of otitis media with effusion in kindergarten children in Taegu area. Korean J Otolaryngol-Head Neck Surg 1995;38:1695-703.

3) Lee HJ, Park SK, Choi KY, Park SE, Chun YM, Kim KS, et al. Korean clinical practice guidelines: otitis media in children. J Korean Med Sci 2012;27(8):835-48.

4) Ovesen T, Paaske PB, Elbrönd O. Accuracy of an automatic impedance apparatus in a population with secretory otitis media: principles in the evaluation of tympanometrical findings. Am J Otolaryngol 1993; 14(2):100-4.

5) Jerger J. Clinical experience with impedance audiometry. Arch Otolaryngol 1970;92(4):311-24.

6) Keefe DH, Bulen JC, Arehart KH, Burns EM. Ear-canal impedance and reflection coefficient in human infants and adults. J Acoust Soc Am 1993;94(5):2617-38.

7) Margolis RH, Goycoolea HG. Multifrequency tympanometry in normal adults. Ear Hear 1993;14(6):408-13.

8) Voss SE, Allen JB. Measurement of acoustic impedance and reflectance in the human ear canal. J Acoust Soc Am 1994;95(1): 372-84.

9) Margolis RH, Hunter LL, Giebink GS. Tympanometric evaluation of middle ear function in children with otitis media. Ann Otol Rhinol Laryngol Suppl 1994;163:34-8.

10) Shahnaz N, Polka L. Standard and multifrequency tympanometry in normal and otosclerotic ears. Ear Hear 1997;18(4):326-41.

11) Margolis RH, Saly GL, Keefe DH. Wideband reflectance tympanometry in normal adults. J Acoust Soc Am 1999;106(1):265-80.

12) Keefe DH, Folsom RC, Gorga MP, Vohr BR, Bulen JC, Norton SJ. Identification of neonatal hearing impairment: ear-canal measurements of acoustic admittance and reflectance in neonates. Ear Hear 2000; 21(5):443-61.

13) Feeney MP, Sanford CA. Age effects in the human middle ear: wideband acoustical measures. J Acoust Soc Am 2004;116(6):354658.

14) Vander Werff KR, Prieve BA, Georgantas LM. Test-retest reliability 
of wideband reflectance measures in infants under screening and diagnostic test conditions. Ear Hear 2007;28(5):669-81.

15) Shahnaz N, Bork K. Wideband reflectance norms for Caucasian and Chinese young adults. Ear Hear 2006;27(6):774-88.

16) Beers AN, Shahnaz N, Westerberg BD, Kozak FK. Wideband reflectance in normal Caucasian and Chinese school-aged children and in children with otitis media with effusion. Ear Hear 2010;31(2): 221-33.

17) Keefe DH, Ling R, Bulen JC. Method to measure acoustic impedance and reflection coefficient. J Acoust Soc Am 1992;91(1):470-85.

18) Feeney MP, Grant IL, Marryott LP. Wideband energy reflectance measurements in adults with middle-ear disorders. J Speech Lang Hear Res 2003;46(4):901-11.

19) Keefe DH, Simmons JL. Energy transmittance predicts conductive hearing loss in older children and adults. J Acoust Soc Am 2003;114(6 Pt 1):3217-38

20) Liu YW, Sanford CA, Ellison JC, Fitzpatrick DF, Gorga MP, Keefe DH. Wideband absorbance tympanometry using pressure sweeps: system development and results on adults with normal hearing. J Acoust Soc Am 2008;124(6):3708-19.

21) Sanford CA, Keefe DH, Liu YW, Fitzpatrick D, McCreery RW, Lewis DE, et al. Sound-conduction effects on distortion-product otoacoustic emission screening outcomes in newborn infants: test performance of wideband acoustic transfer functions and 1-kHz tympanometry. Ear Hear 2009;30(6):635-52.

22) Holte L, Margolis RH, Cavanaugh RM Jr. Developmental changes in multifrequency tympanograms. Audiology 1991;30(1):1-24.

23) Paradise JL, Smith CG, Bluestone CD. Tympanometric detection of middle ear effusion in infants and young children. Pediatrics 1976; 58(2):198-210.

24) Cho YS, Lee DK, Lee CK, Ko MH, Lee HS. Video pneumatic otoscopy for the diagnosis of otitis media with effusion: a quantitative approach. Eur Arch Otorhinolaryngol 2009;266(7):967-73.

25) Cumming G, Finch S. A primer on the understanding, use, and calculation of confidence intervals that are based on central and noncentral distributions. Educ Psychol Meas 2001;61(4):532-74.

26) Doan DE, Erulkar JS, Saunders JC. Functional changes in the aging mouse middle ear. Hear Res 1996;97(1-2):174-7.

27) Werner YL, Montgomery LG, Safford SD, Igic PG, Saunders JC. How body size affects middle-ear structure and function and auditory sensitivity in gekkonoid lizards. J Exp Biol 1998;201(Pt 4):487-502.

28) Colin Bell A, Adair LS, Popkin BM. Ethnic differences in the association between body mass index and hypertension. Am J Epidemiol 2002;155(4):346-53.

29) Ellison JC, Gorga M, Cohn E, Fitzpatrick D, Sanford CA, Keefe $\mathrm{DH}$. Wideband acoustic transfer functions predict middle-ear effusion. Laryngoscope 2012;122(4):887-94.

30) Keefe DH, Zhao F, Neely ST, Gorga MP, Vohr BR. Ear-canal acoustic admittance and reflectance effects in human neonates. I. Predictions of otoacoustic emission and auditory brainstem responses. J Acoust Soc Am 2003;113(1):389-406.

31) Prieve BA, Vander Werff KR, Preston JL, Georgantas L. Identification of conductive hearing loss in young infants using tympanometry and wideband reflectance. Ear Hear 2013;34(2):168-78

32) Jaisinghani VJ, Paparella MM, Schachern PA, Schneider DS, Le CT. Residual mesenchyme persisting into adulthood. Am J Otolaryngol 1999;20(6):363-70.

33) Miura T, Suzuki C, Otani I, Omori K. [Marrow-tympanum connections in fetuses and infants]. Nihon Jibiinkoka Gakkai Kaiho 2008;111 (1):14-20

34) Hunter LL, Feeney MP, Lapsley Miller JA, Jeng PS, Bohning S. Wideband reflectance in newborns: normative regions and relationship to hearing-screening results. Ear Hear 2010;31(5):599-610. 